American Research Journal of Agriculture

ISSN (Online) : 2378-9018

Volume 5, Issue 1, 1- 16 Pages

DOI: 10.21694/2378-9018.19003

\title{
Agronomic Measures in Traditional Soil and Water Conservation Practices in the Sikkim Himalaya, India
}

\author{
Prabuddh Kumar Mishra*1, Aman Rai ${ }^{2}$, Suresh Chand Rai ${ }^{3}$ \\ ${ }^{1,2}$ Department of Geography, Shivaji College, University of Delhi, India. \\ ${ }^{3}$ Professor, Department of Geography, Delhi School of Economics, University of Delhi, India. \\ prabuddh@shivaji.du.ac.in
}

\begin{abstract}
In the era of global environmental and biophysical change, an enhanced focus has been given to conservation of the mountain ecosystem through traditional knowledge system. Traditional soil and water conservation practice play a vital role in the conservation and management of mountain ecosystem, but recently, soil erosion has emerged as one of the serious problems. Mountains being one of the most fragile and vulnerable ecosystems are also suffering from various drivers of change. Soil erosion in the mountains is one of the most prominent factors leading to the depletion of soil fertility and in turn, affects the yield capacity of the soil. In this context, the study was carried out in an agrarian watershed of Sikkim Himalaya. Data used for the study were collected during the year 2017-18 through a household survey of 300 farmers, focus group discussions, key informant interviews and field observation. Based on the data, various indigenous soil and water conservation practices were identified and documented. Farmers in the watershed are practising several land management techniques to conserve soil and water resources. Dominant indigenous soil and water conservation techniques identified in the watershed are mechanical, agronomic/biological measures and soil fertility management measures. These indigenous conservation measures are based on the farmer's experience of agricultural practices over a long period and are passed on from one generation to the other. This study is an attempt to understand the traditional agronomic measures used by farmers of Rani Khola watershed to minimise soil erosion and increase the productivity of the land. The traditional techniques are not only useful in conserving soil and water but also give higher economic benefits to the farmers. The study provides an insight on agronomic ways of soil and water conservation, increasing agricultural productivity and livelihood security of the local community.
\end{abstract}

Keywords: Soil and water conservation, agronomic measures, traditional knowledge, Rani Khola watershed, Sikkim Himalaya.

\section{INTRODUCTION}

Soil and water are among the most precious natural resources on the planet earth. The formation of one centimetre of soils takes 100 years, while deterioration only takes a few years (Gautam, 1993). The problem of land degradation started since humans started domesticating plants, animals and settled the land (Sanders, 2004). According to UNCCD (2004), since 1990 every year over six million hectares of productive land is being lost globally due to land degradation. Deforestation, urbanization, overgrazing, unsustainable land use, intensive cultivation and inappropriate land management techniques are the leading causes of land degradation. Erosion of soil by water is the most widespread form of soil degradation globally (Garcia-Ruiz et al., 2017; Maetens et al., 2012) and it depends on various factors such as slope, soil properties, vegetation cover, rainfall intensity and amount (Selby, 1993). Studies conducted in the Himalayan region reported soil erosion as one of the primary factors in agricultural land degradation (Gardner and Gerrard, 2003; Uddin et al., 2016; Chalise et al., 2018; 
Agronomic Measures in Traditional Soil and Water Conservation Practices in the Sikkim Himalaya, India

Carson, 1985; Mishra, 2017; Rai and Sharma, 1998a). Agricultural practices in hilly areas without tree cover can reduce soil fertility due to increased soil erosion (Rai and Sharma, 1998a). Soil erosion leads to depletion of soil fertility and decreases soil moisture storage capacity which results in decreased crop productivity.

In Sikkim Himalaya livelihood of the people are mainly based on subsistence farming (Sharma et al., 2001). Intensive agricultural practices are vulnerable to soil erosion and lead to reduced soil fertility (Rai and Sharma, 1995). Soil erosion not only affects agricultural production but it also disturbs environmental and ecological functions performed by soil. Soil erosion in agricultural lands is one of the major socio-environmental issues in the Himalayan region (Rai and Sharma, 1998a; Rai and Sharma, 1998b; Mishra and Rai, 2013). Soil erosion cannot be prevented in totality however, it can be minimised (Morgan, 2005). To prevent soil erosion, several conservation techniques have been widely used around the world and broadly classified into mechanical, agronomic /biological and soil fertility management measures (Morgan, 2005; FAO, 1984). To minimize the problem of soil erosion, adaptation of suitable soil and water conservation (SWC) measures and cultivating suitable crops is the most critical factor (Manivannan et al., 2017). The conservation measures adopted in the cropping system is called agronomic measure (Morgan, 2005). It functions by reducing overland flow and runoff while increasing the infiltration (Tidemann, 1996). Several agronomic measures for SWC (crop rotation, strip cropping, contour tillage, mixed cropping, mulching and minimum tillage) are used to minimise soil erosion and maximise agricultural production. However, all techniques are not suitable or practical in all the places.

A wealth of evidence indicates the need for diverse solutions to the existing challenges in socio-ecological systems. To minimise the effects of soil erosion and conserve soil and water resources, several traditional land management practices are used in Sikkim Himalaya. Traditional knowledge of the farmers are based on the local climate, slope, environmental biodiversity, resources, local requirements and the knowledge is handed down from one generation to other (Mishra and Rai, 2013). This knowledge of the farmers helps them to identify the suitable conservation measure for a particular land. According to Mishra and Rai (2014), traditional SWC techniques not only prevent soil erosion but also increase crop yield and soil fertility. The traditional knowledge of farmer around the world has attracted the interest of researchers and various studies on traditional knowledge of SWC have been conducted (Lalonde, 1991; Rai and Sharma, 1994; IIRR, 1996; Ajibade, 2003; Mulat, 2013; Mishra and Rai, 2013). The present study attempts to explore the traditional agronomic measures of the Rani Khola watershed of Sikkim Himalaya and its various facets including the innovative farming techniques developed by farmers and examine their importance concerning recent socio-economic and environmental changes in the region.

\section{Study Area}

Rani Khola watershed lies in the east district of Sikkim Himalaya covering an area of $254 \mathrm{~km}^{2}$ between the latitudes $27^{\circ} 13^{\prime} 9 \mathrm{~N}$ to $27^{\circ} 23^{\prime} 51 \mathrm{~N}$ and longitude $88^{\circ} 29^{\prime} 31 \mathrm{E}$ to $88^{\circ} 43^{\prime} 18 \mathrm{E}$ (Fig. 1). Elevation ranges between $311 \mathrm{~m}$ to $4112 \mathrm{~m}$ asl. The watershed is named after the major river of the watershed Rani Khola, also known as Rongni chu in the local dialect that drains into river Teesta. The river receives water from many tributaries on both sides of its course. The primary sources of water in the watershed are springs, streams (Dhara) and small rivers (Khola). Vegetation in this watershed consists of the subtropical broad-leaved evergreen forest, mixed coniferous forest, cool broad-leaved forest (Rumtek, Rorathang), lauraceous forest (Pakyong, Gangtok), buk oak forests, sub-alpine, alpine scrub and alpine pasture. Fambong Lho Wildlife Sanctuary and Kyongnosla Alpine Sanctuary are the famous sanctuaries of Sikkim Himalaya both of them partially lies in the watershed. Reserved forests such as Martam Reserved Forest; Bhusuk Reserved Forest and Assam Reserved Forest enrich the floral diversity of the area. Climatically, the watershed enjoys sub-tropical to alpine climatic conditions. The average 
Agronomic Measures in Traditional Soil and Water Conservation Practices in the Sikkim Himalaya, India

temperature of the watershed ranges from an average maximum of $22^{\circ} \mathrm{C}$ during summer and $4^{\circ} \mathrm{C}$ during the winter season. Majority of the area in the watershed is rural with a total population of 161394 and average density of 635 person $/ \mathrm{km}^{2}$ (COI, 2011). Watershed is characterised by traditional agricultural systems and the majority of the farmers are marginal farmers. Major crops grown in the watershed are ginger, paddy, wheat, maize, cardamom, pulses and vegetables. Other allied activities are animal husbandry and livestock farming.

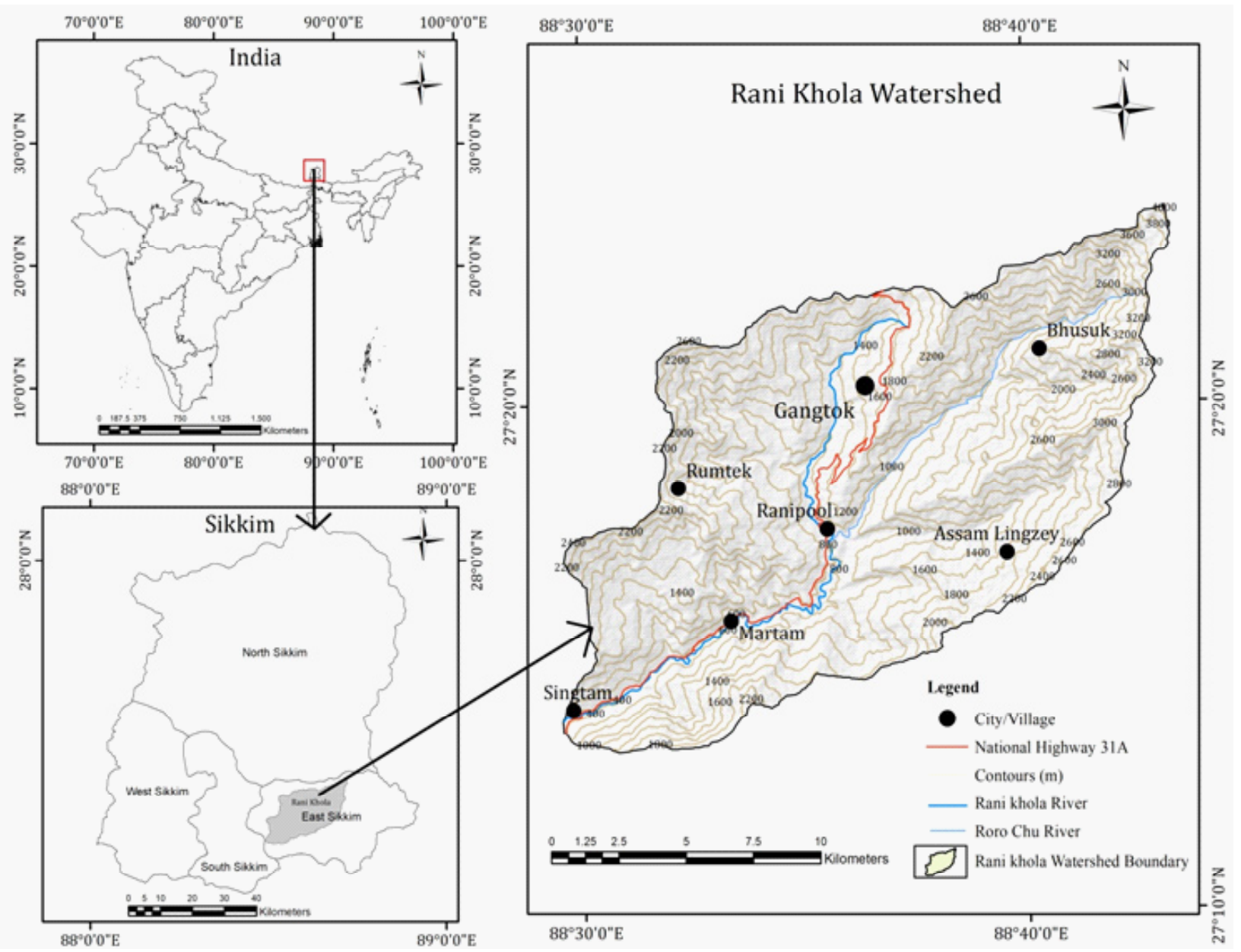

Fig1. Location Map of the Rani Khola Watershed

\section{MeTHODOLOGY}

Data used for the study were collected through a household survey, focus group discussions, key informant interviews and field observation on documenting information regarding the role of agronomic measures in SWC and agricultural production system of the watershed during the year 2017-18. The study area was classified into three ecological zones based on elevation, i.e. low (300m to $800 \mathrm{~m})$, mid ( $801 \mathrm{~m}$ to $1500 \mathrm{~m})$ and high (1501m and above) (Fig. 2). Majority of the agricultural activities in the watershed is performed within the altitudes of $400 \mathrm{~m}$ to $2000 \mathrm{~m}$. Stratified random sampling method for the questionnaire survey was adopted for 300 households. About 100 households were selected from 5 villages in each ecological zone, i.e. low, mid and high. In case of absence of the selected household head, a random substitute was included. Data were collected using a structured questionnaire that requested information about traditional SWC conservation techniques and agricultural production system. The questionnaire was designed to elicit information, i.e., socio-economic 
status of the household, landholding, existing farming systems, crop preferences, farmers perceptions of soil erosion, conservations measures used by farmers and other indigenous techniques regarding soil and water conservation. Along with this, the main aim of the focus group discussions was to understand the farmer's perspective of existing problems of soil erosion, their attitude towards the problem and the significant environmental and socio-economic impacts of the conservation measures.

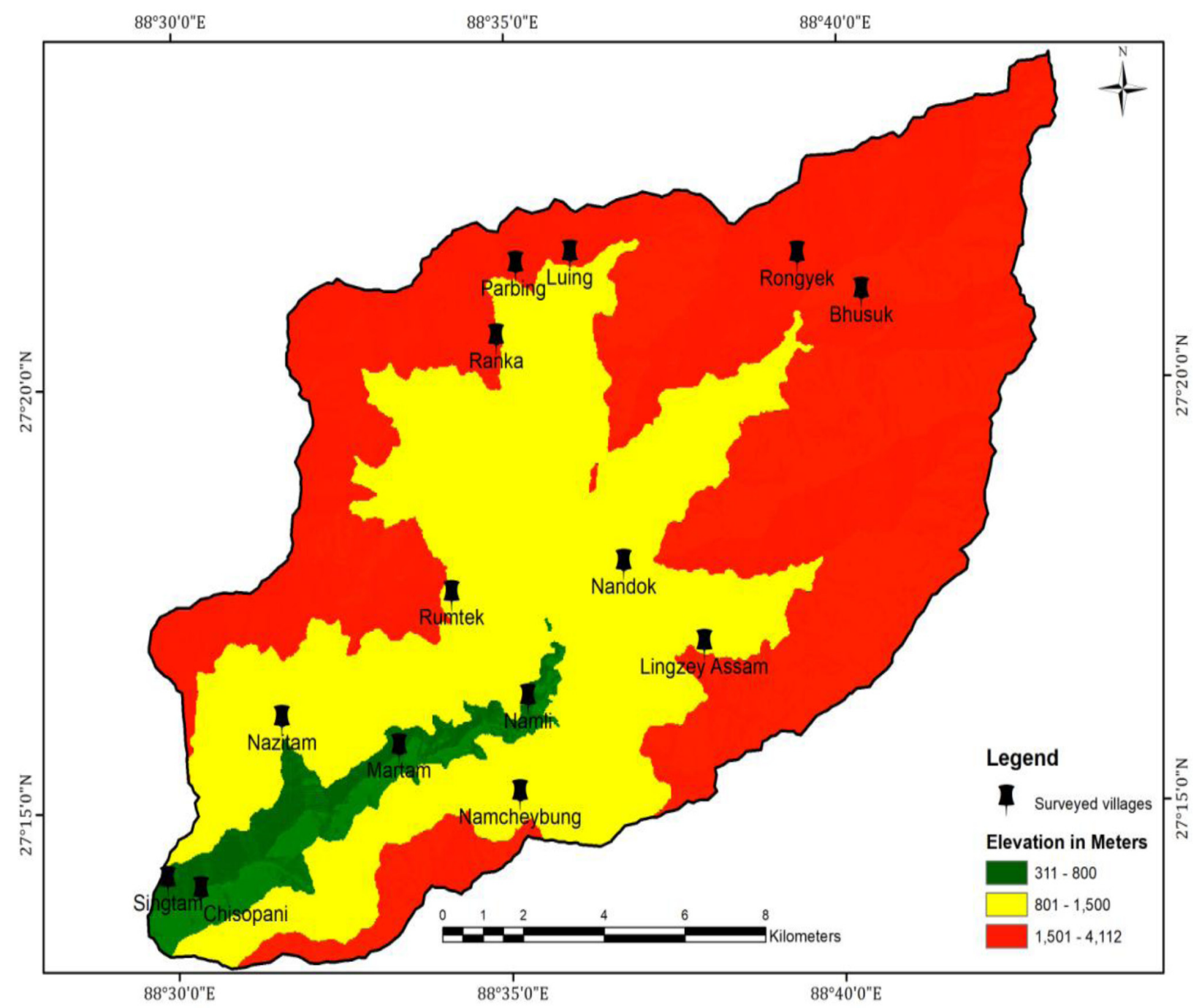

Fig2. Ecological Zones and sample Villages in Rani Khola Watershed of Sikkim Himalaya

\section{Characteristics of Households}

Agriculture is the principal economic activity of the watershed, about $24.03 \%$ of the total working population are cultivators and $5.04 \%$ are agricultural labourers. Data obtained through survey revealed that majority of the respondent families are the nuclear and the average size of the households is 4 . About $47 \%$ of the respondents in all the ecological zones are marginal with less than 0.5 ha of land. Farmers with medium size land holdings are 30 while large landholding farmers are $18 \%$ in the lower ecological zone and $25 \%$ in middle and higher ecological zones. Given the structured sampling procedure employed, large sample size, wide distribution of respondents over each of ecological zones and the high response rate, it is argued that the samples are representative of study population in the watershed. Characteristics of respondent are presented in Table 1. 
Agronomic Measures in Traditional Soil and Water Conservation Practices in the Sikkim Himalaya, India

Table1. Characteristics of the study respondents of Rani Khola watershed of Sikkim Himalaya $(n=300)$

\begin{tabular}{|l|l|l|l|}
\hline \multirow{2}{*}{\multicolumn{2}{|c|}{ Parameters }} & \multicolumn{3}{c|}{ Ecological Zones } \\
\cline { 2 - 4 } & Low & Mid & High \\
\hline Number of Households Surveyed & 100 & 100 & 100 \\
\hline Male (No.) & 72 & 87 & 69 \\
\hline Female (No.) & 28 & 13 & 31 \\
\hline Size of Household (Person/HH) & 4.3 & 4.1 & 3.9 \\
\hline Age in Years (Mean) & 56.06 & 58.29 & 59.45 \\
\hline Days usually worked off-farm (Mean) & 61 & 75 & 57 \\
\hline Land Holdings (\%) & \multicolumn{5}{|l}{} \\
\hline Marginal (<0.5 ha) & 47 & 49 & 46 \\
\hline Medium (0.5-1 ha) & 35 & 26 & 29 \\
\hline Large $(>1$ ha) & 18 & 25 & 25 \\
\hline
\end{tabular}

\section{Existing Farming Systems}

Farming on mountains involve the use of local raw materials and indigenous techniques (Mountjoy and Gliessman, 1988; Hawtin and Mateo, 1990), these farming systems are managed traditionally by local farmers and the farming techniques evolve over a long period of time by farmers through trial and error method (Rai and Sharma, 1994). Agriculture is the backbone of the Sikkim state's economy (Subba, 2009) and more than 64\% of the population of Sikkim directly or indirectly depends on agriculture for their livelihood. Agriculture is one of the primary source of livelihood in rural areas of the watershed with $17.63 \%$ area under agriculture (Mishra et al., 2019). Watershed is characterised by strong traditional agroforestry base and supports four basic farming systems viz; agriculture, horticulture, agroforestry and animal husbandry, all of which are livestock based and responsive to climate, topography and resource availability. Major crops grown in the watershed are ginger, paddy, wheat, maize, pulses and vegetables. Farmers intercrop rice with a traditional variety of soybean, rice bran and on terrace bunds. The rice-wheat, rice-mustard, rice-potato, rice-fallow, maize-rice-mustard (below $800 \mathrm{~m}$ ) and maize-rice-fallow at higher hills are common cropping systems on irrigated terrace rice lands. Most of the crops are grown as food crops from March to September. A large number of landraces of maize, paddy, buckwheat, beans, pulses, finger millets, yams, tubers and ginger are grown in rotation, among these maize holds the highest rank followed by paddy in the watershed. Maize is grown up to 2,700m elevation while paddy is grown up to $1500 \mathrm{~m}$.

\section{Land Degradation in Rani Khola Watershed}

Variation of topography and land use pattern within the region produce different genres of land degradation. Each ecological zones of the watershed experience different land degradation problems (Table 2) and severity of the problem depends on various factors such as slope, vegetation cover, soil type and intensity of rainfall. For example, in the higher ecological zones vegetation devoid areas with steep slope experience frequent landslides and slope failure, while in the gentler slopes the damage is only limited to soil erosion. On the other hand, the intensity of sheet erosion during the monsoon season is higher in the barren lands of all ecological zones. During the focus group discussions, farmers informed that major land degradation in the watershed are landslides, mass wasting, slope or terrace failure, rill erosion, sheet erosion, river bank expansion and soil erosion through the overland flow. In the agricultural field, slope failure, gully erosion, sheet erosion and soil erosion are the major issues. Soil erosion along with seasonal water scarcity, increasing population, poverty and fragmentation of farm families are responsible for decreasing productivity. When deciding what conservation measures to 
Agronomic Measures in Traditional Soil and Water Conservation Practices in the Sikkim Himalaya, India

employ, farmers always give preference to agronomic treatment as these are usually less expensive and directly deals with reducing raindrop impact, runoff volumes, water velocity while increasing infiltration and organic matter in the soil profile. Farmers reported that the uses of agronomic measures are not only limited to the agricultural land but also used to prevent the slope failure, gully erosion and landslides by planting bamboo trees in the fragile and vulnerable areas of the watershed.

Table2. Existing land degradation types in the watershed

\begin{tabular}{|l|l|l|}
\hline \multicolumn{1}{|c|}{ Ecological Zone } & \multicolumn{1}{|c|}{ Elevation (m) } & \multicolumn{1}{c|}{ Land Degradation Types } \\
\hline Higher & $1501-4100$ & Landslides, mass wasting, rill erosion, gully erosion, soil erosion \\
\hline Middle & $801-1500$ & Landslides, rill erosion, gully erosion, soil erosion \\
\hline Lower & $311-800$ & Sheet erosion, rills, river bank expansion, soil erosion \\
\hline
\end{tabular}

\section{RESULT}

\section{SWC and Agronomic Measures}

Several agronomic/biological measures of soil and water conservation are used in the watershed such as alley cropping, agroforestry, vegetative barriers, crop rotation, mixed cropping, mulching, minimum tillage and fallowing (Table 3 and Fig. 3). Construction and maintenance cost of SWC measures largely determine the adoption of all the conservation techniques. Among others, availability of labours, raw material, the slope of the area, the stability of the terraces, payback period of the practices and production capacity worth mentioning. In the field survey, it was observed that about all of the respondents were practising some SWC techniques based on the local conditions and affordability.

Table3. Soil and water conservation measures in Rani Khola Watershed ( $n=300)$

\begin{tabular}{|l|l|l|l|l|}
\hline \multirow{2}{*}{ SWC Measures } & \multicolumn{4}{|c|}{ Ecological Zones } \\
\cline { 2 - 5 } & Low $(\mathrm{n}=100)(\%)$ & Mid (n=100) (\%) & High (n=100) (\%) & Mean \% \\
\hline Crop Rotation & 100 & 100 & 100 & 100 \\
\hline Mixed Farming & 82 & 91 & 94 & 89 \\
\hline Minimum Tillage & 82 & 78 & 70 & 76.6 \\
\hline Mulching & 84 & 89 & 90 & 87.6 \\
\hline Fallowing & 17 & 22 & 14 & 17.6 \\
\hline Alley Cropping & 32 & 29 & 25 & 28.6 \\
\hline Vegetative Barriers & 100 & 100 & 100 & 100 \\
\hline agro forestry & 24 & 63 & 70 & 52.3 \\
\hline Farm Yard Manure & 100 & 100 & 100 & 100 \\
\hline Green Manure & 58 & 56 & 60 & 58 \\
\hline Crop residue and weed burning & 42 & 39 & 23 & 34.6 \\
\hline
\end{tabular}

\section{Crop Rotation}

Crop rotation refers to the technique of growing different types of crops in consecutive seasons in a same area. It provides several benefits such as high diversity in crop and nutrient protection, breaks the cycle of diseases, pests and weed, various types of plants with different root shape and sizes improve soil structure, humus formation, distribution of water and nutrients through soil profiles by roots of different plant spices. It also avoids the excessive depletion of nutrients present in the soil. Preferences are given to the crops based on several factors, such as which crop can retain soil fertility of the area, which type of conservation measure is 
required on what kind of slope, which crops yield higher while intercropping with other, which crop is suitable for pest and weed control. Crop rotation is one of the most widely used agronomic SWC techniques in this watershed. About $100 \%$ of the respondents in all ecological zones agreed that they follow crop rotation reason being, it maintains the soil fertility level and is financially most suitable for farmers as it helps them cultivate crops throughout the year (Table 3). Other benefits reported by respondents are a reduction in pest effect, insects and diseases and increase of humus in the soil profile.

\section{Mixed Cropping}

Farmers of the watershed follow mixed cropping for better production and soil conservation. To increase the efficiency of land-use several methods are used such as maximising the production of a single cash crop, cultivation of two crops or cultivation of multiple crops know as mixed cropping. In mixed farming two or more crops are grown in the same field at the same time, it is also known as intercropping. Mixed cropping is also widely practised by the farmers. About $82 \%$ of respondents in lower ecological zones are practising mixed farming, while in the mid and high ecological zone it was $91 \%$ and $94 \%$ respectively (Table 3). Most of the farmers grow maize as the main crop along with vegetables and pulses. According to the farmers mixed cropping offers them several benefits such as increased productivity, low weed, full use of limited land and nutrient recourses, diversity of crops, pests control. Except for paddy, almost all the crops in the watershed are grown with various other crops, shrubs, herb or trees. Cropping pattern in the watershed are classified into four broad categories, i.e. (i) maize-pulse combination, and ginger in sub-tropics (ii) maize-potato in temperate (iii) Khet or paddy fields (iv) large cardamom based agroforestry. The intensity of cropping changes among the households based on the socio-economic conditions, notably inputs and products, dependence on land and tenurial system.

\section{Conservation Tillage/Minimum Tillage}

Conservation tillage or minimum tillage is a method of seedbed preparation where the land surface is left least disturbed. The intensity of the technique is dependent on factors like climate, slope, soil properties, crop preference and other socio-economic factors. The techniques range from reduced or no-till to more intensive tillage. In the watershed, it is done with animal traction using a wooden plough or a mould board plough. The farmers stated that the amount of soil loss is less in the minimum tillage plots than in the ploughed plots. This technique offers minimum soil loss caused by wind and water and less labour intensive than other tillage techniques. It is also one of the widely practised SWC measures in the watershed. About $76.6 \%$ of the respondents are practising minimum tillage in the watershed the percentage is more in mid $78 \%$ and lower ecological zone $82 \%$ than in higher $70 \%$ due to the bigger size of the fields in the lower ecological zone (Table 3).

\section{Mulching}

Most of the farmers practice mulching by using crop residue to provide a protective cover at the time when crops are not grown. Majority of the farmers are practising mulching on their fields as they are well aware of the benefits of protective covering. According to the respondents it helps to retain soil moisture, protects the crop from the rainstorm and increases organic matter in the soil as the material used for mulching decays with time. $87.6 \%$ of respondents are practising mulching in the watershed; the percentage is less in low ecological zone $84 \%$ as compared to mid $89 \%$ and high ecological zones $90 \%$ due to decreasing temperature with altitude (Table 3).

\section{Fallowing}

Fallowing refers to the process of leaving the agricultural land without planting any corps for some time to improve it's soil fertility. Fallowing is the least used agronomic techniques of the watershed as the pressure of increasing population on agricultural land is very high and half the farmers of this watershed are marginal, 
Agronomic Measures in Traditional Soil and Water Conservation Practices in the Sikkim Himalaya, India

$17.6 \%$ of the total respondents have reported that they leave their agricultural land for fallowing. Only $17 \%$ of the respondents in the lower ecological zone accepted practicing this technique in the middle and higher ecological zones percentage of respondents practicing fallowing was $22 \%$ and $14 \%$.
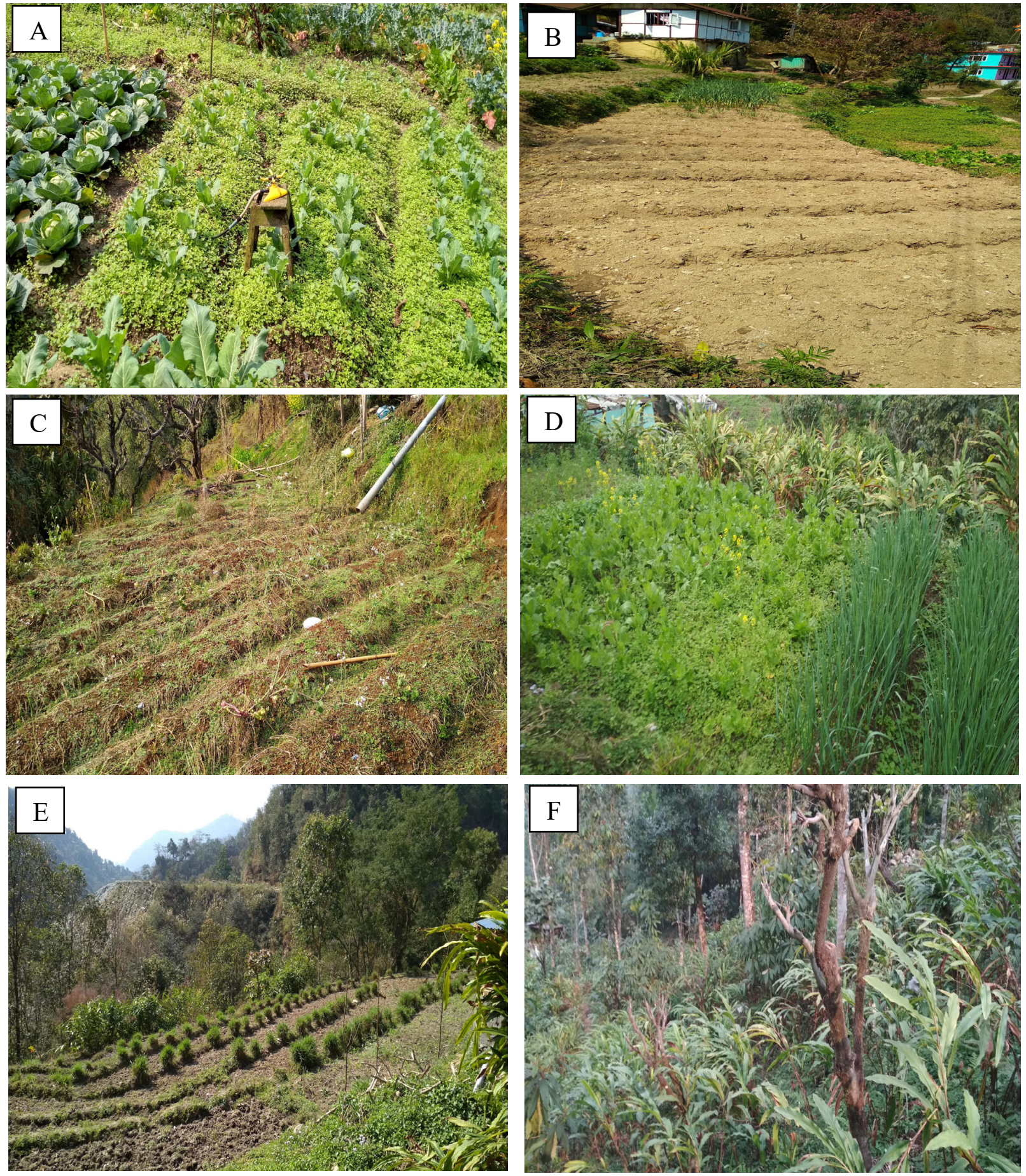

Fig3. Photograph of traditional agronomic measures used for SWC conservation in the watershed; (A) mixed farming; (B) contour tillage; (C) land left for fallowing process; (D) alley cropping; (E) vegetative barriers, and; (F) large cardamom based agroforestry 
Alley Cropping

Alley cropping refers to the plantation of plants or trees in rows within the agricultural crop system. It is a way to diversify cropping system and income, thereby improving the return on long-term investments in trees. Farmers are of the view that alley cropping helps to increase soil moisture, overall farm production, reduces soil erosion, pests and disease. Overall the percentage of farmers practising alley cropping in the watershed is low as it requires longer time horizon to provide cash flow and shrinking landholdings of the farmers creates pressure on farmers to get higher profits in short duration. In the watershed peas, beans, soybean and fodder plants are grown as alley crops. About $28.6 \%$ of the respondents mentioned that they are practising alley cropping. This was recorded to be the highest in lower ecological zone $32 \%$ while in middle and higher ecological zones it was practised by $29 \%$ and $25 \%$ of the respondents respectively (Table 3 ).

\section{Vegetative Barriers}

Vegetative barriers are usually grass planted in narrow strips along the contours of the field. All respondents were using vegetative barriers in their agricultural lands in all ecological zones (Table 3). It acts similar to other barriers and helps in decreasing the velocity of runoff, contains soil moisture throughout the year and traps moving soil near the roots. Apart from minimising the soil erosion and preventing gully formation vegetative barriers are also used to generate income and food for livestock. A verity of fodder plants/grasses (Amlisho and Napier), Pulses (Kalo Dalo, Paili/arhar Dal,Masem, Bhatmas) and fodder trees (Nebharo, Badahar, Nimaro, Khanyu, Gagun, Mahula, Bakaino, Kabra, Khanium) are grown on earthen bunds in terraces while on sloping terraces other fruit plants/trees (Kela, Suntola, Nashpati, Arucha, Meva) are grown which provide nutrients to soil and are financially beneficial for farmers.

\section{Agroforestry}

During the field survey, physical observation of farms in the study villages revealed that the farmers living closer to streams and rivers developed elaborate agroforestry system. Agroforestry is one of the significant conservation practises in the Sikkim Himalaya. The watershed is characterised by different types of agroforestry systems, i.e. farm based agroforestry, farm forest-based agroforestry and high-value cash crops based agroforestry. The agroforestry plants and the fodder plants are the major agroforestry crops of the watershed along with spices crops (large cardamom, turmeric, ginger), fruit crops (Sikkim mandarine orange, pineapple). Large cardamom is one of the major commercial crops and Sikkim is the largest producer of cardamom in India. It is adapted well as agroforestry crops from $600-1,800 \mathrm{~m}$ elevations of humid environments on steep sloppy hills under shade trees where other economic crops cannot be grown. Mandarin orange also has the potential for high-value cash crops after large cardamom and comparatively less labour intensive crop. The Himalayan alder (Alnus nepalensis) is the most common species adopted in this system. Most of the mountain cultivated land is under diverse agroforestry systems to reduce soil erosion and ensure substantial production. Bamboo groves and other fuelwood/timber species are also grown in a parcel of land to restore the degraded slopes and landslide areas. Bans-ghari at the edge of the agriculture fields prevent landslides, soil loss and provide household requirements. According to the farmers, it is the best agricultural practices with minimum soil erosion. Agroforestry is mostly practised on non-terraced slopes in middle and higher ecological zones where the slope of the land is relatively higher than lower ecological zones. In the lower ecological zones, about $24 \%$ of respondents are practising agroforestry as the majority of the land has been converted into a levelled terrace for paddy cultivation. Agroforestry is widely practised in mid and high ecological zones, $63 \%$ and $70 \%$, respectively (Table 3). Overall $52.3 \%$ of the respondents agreed that they practise agroforestry on their lands for SWC conservation and high economic return. In the watershed agroforestry practices are the most successful examples of crop diversification which not only provide crops for farmer's subsistence needs and earning of cash income but also help amelioration of landscape through conservation of native biodiversity in the abandoned shifting cultivation plots and home gardens. 
Agronomic Measures in Traditional Soil and Water Conservation Practices in the Sikkim Himalaya, India

\section{Farm Yard Manure}

Given the changing conditions, needs and insights, farmers continually adapt their soil fertility management practices. Since the ban in the state on chemical fertiliser (2005), old soil fertility practices have reversed and about $100 \%$ of the farmers use FYM in the watershed. FYM refers to the organic manure derived from plants and animal resources. FYM is mainly derived from livestock (pellets and urine of sheep, goats, poultry, and cow), waste fodder, tree leaves and crop weeds. These materials are collected and exposed to the sun, wind and rain for several weeks before transferring to the fields. It is the primary source of fertilisers in the watershed. All the respondents in all ecological zones were using FYM in their agricultural lands. Farmers who do not own any livestock buy FYM from other farmers at very low cost.

\section{Green Manures}

Green manure is prepared by integrating green manure crop's green leaves into the soil to increase the fertility of the soil. These crops are nitrogen-fixing plants which are usually grown, ploughed and incorporated with soil on the same plot, sometimes the legumes or non-legumes crops are brought from outside and then applied on the land. Conventional green manures found in the watershed are Adhatoda vasica, Euphorbia roylena, Artemissia vulgaris spp. About $58 \%$ of respondents in the lower ecological zone are using green manure while in middle and upper ecological zones it is used by $56 \%$ and $60 \%$ respectively. Overall $58 \%$ of the respondent in watershed agreed using green manure in their agricultural lands (Table 3).

\section{Crop Residue and Weed Burning}

Crop residue and weed burning have become an issue of environmental concern. Farmers revealed that burning weed and crop residue decreased over the past few years, instead of burning they are using it as fodder since grazing is banned and marginal farmers who cannot grow fodder plants are bound to use crop residue and weed as fodder for their livestock. However $34.6 \%$ of the respondents agreed that they burn crop residue and weed in their field. Farmers in lower ecological zones $42 \%$ were practising this more as compared to farmers in the middle and upper ecological zones, i.e. $39 \%$ and $23 \%$, respectively. A reason for this is that lower and middle zones have more levelled terraces whereas in the upper zone more cultivated land is under agroforestry (Table 3).

During the field survey and focus group discussion, farmers were asked about the environmental and economic sustainability of the SWC practices along with its social viability Table 4. Farmer's perception of environmental sustainability was primarily determined by the effectiveness of SWC practice to reduce erosion while economic sustainability was based on higher production with minimum maintenance and labour cost. In the watershed, indigenous knowledge is effective in reducing soil erosion and improving the management of soil and water resources to fulfil the increasing food demand. These practices are not only beneficial for maintaining natural resources, but they also provide higher yields which further increases the resilience of marginal farmers to fight problems like poverty and climate change. It helps them to provide better livelihood opportunity using locally available raw material and resources.

Table4. Evaluation of the SWC measures in the Rani Khola Watershed

\begin{tabular}{|c|c|c|}
\hline Measures & Ecological Imapcts & Economic and Social Impacts \\
\hline $\begin{array}{l}\text { Crop Rotation/ } \\
\text { Mixed Farming }\end{array}$ & $\begin{array}{l}\text { - Reduces soil erosion/Erosion control } \\
\text { - Maintains soil nutrient, fertility and organic } \\
\text { content } \\
\text { - Reduces pest and disease, } \\
\text { - Prevents crop failure }\end{array}$ & $\begin{array}{l}\text { - } \text { Diversifies production } \\
\text { - Increases production } \\
\text { - Lower risk of loss } \\
\text { - Maximises use of land } \\
\text { - } \text { Suitable for marginal farmers } \\
\end{array}$ \\
\hline Minimum Tillage & - Suited for poorly drained soil & - Minimise labour cost \\
\hline
\end{tabular}

American Research Journal of Agriculture

Page 10 
Agronomic Measures in Traditional Soil and Water Conservation Practices in the Sikkim Himalaya, India

\begin{tabular}{|c|c|c|}
\hline Mulching & $\begin{array}{l}\text { - } \text { Protective cover for soil. } \\
\text { - Reduces soil erosion } \\
\text { - Increases soil moistureand } \\
\text { retention, } \\
\text { - Prevents weed growth }\end{array}$ & $\begin{array}{l}\text { - Maximise crop yield } \\
\text { - Less input cost } \\
\text { - Fewer applications of pesticides and } \\
\text { FYM }\end{array}$ \\
\hline Fallowing & - Helps to restore the fertility of the soil & $\begin{array}{l}\text { - Minimise labour and ox plough } \\
\text { requirement } \\
\text { - Maximise crop yield }\end{array}$ \\
\hline $\begin{array}{l}\text { Alley Cropping } \\
\text { Vegetative Barriers }\end{array}$ & 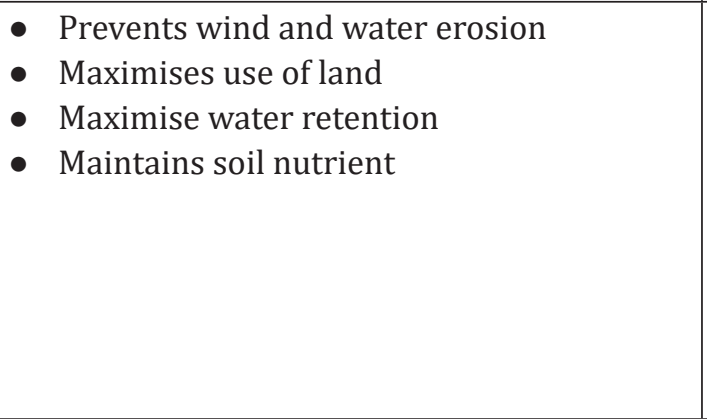 & $\begin{array}{l}\text { - Diversifies production } \\
\text { - Increases production } \\
\text { - Maximises use of land } \\
\text { - Low plantation and maintenance } \\
\text { cost, } \\
\text { - Diversifies production } \\
\text { - Increases production } \\
\text { - Increases income and useful as } \\
\text { fodder crops }\end{array}$ \\
\hline Agroforestry & $\begin{array}{ll}\text { - } & \text { Minimum runoff } \\
\text { - } & \text { Maximise water retention } \\
\text { - } & \text { Works as the carbon sink } \\
\text { - } & \text { Maintains soil nutrient, fertility and organic } \\
\text { content }\end{array}$ & $\begin{array}{l}\text { - Minimum maintenance cost } \\
\text { - Diversifies production } \\
\text { - Increases income and useful as } \\
\text { fodder crops }\end{array}$ \\
\hline $\begin{array}{l}\text { Farm Yard Manure/ } \\
\text { Green Manure }\end{array}$ & $\begin{array}{l}\text { - Increases organic matter } \\
\text { - Increases fertility }\end{array}$ & $\begin{array}{l}\text { - } \text { Increases production } \\
\text { - } \text { Minimum input cost }\end{array}$ \\
\hline $\begin{array}{l}\text { Crop residue and } \\
\text { weed burning }\end{array}$ & $\begin{array}{l}\text { Organic } \\
\text { - Reduces Insects and pests } \\
\text { - Increases fertility } \\
\text { - Pollution by burning weed and crop } \\
\text { residue }\end{array}$ & $\begin{array}{l}\text { - Increases production } \\
\text { - No input cost }\end{array}$ \\
\hline
\end{tabular}

\section{DISCUSSION}

Interestingly, because most ethnic people continue to maintain their traditional food and cultural habits, they still prefer the traditional food crops and SWC measures to conserve their land. In-depth investigations by several studies (FAO, 1984; Tidemann, 1996; Morgan, 2005; Mishra et al., 2013; Manivannan et al., 2017) have observed by working closely with local communities that indigenous practices have a significant role to play in conserving our SWC resources and cultivation systems. Soil erosion is prevented by several mechanical, agronomic/biological and soil fertility management techniques. Farmers have adopted number of conservation measures based on their criteria to evaluate the efficiency of particular conservation measure. These criteria include their social, economic and local physiographic conditions such as slope, altitude, crop preference, the yield capacity of the soil and financial ability to invest in the soil. Along with agronomic/biological measures various mechanical measures such as terracing, bunding, diversion channels are also constructed to reduce the rate of runoff and to hold water for longer duration which increases the infiltration in the agricultural fields. These traditional SWC measures have been devolved based on their decades of practices and knowledge which contribute to long term sustainability of land and maintain agriculture production. However, changes in socioeconomic and environmental conditions prompted farmers to develop innovative farming practices that draw heavily on the principles of traditional knowledge system and modern knowledge system. 
Farmers with large landholdings tend to invest more in mechanical measures if the slope of land holdings is not too steep. Terracing and bunding are the most common mechanical measures in this watershed as the area receives heavy rainfall during monsoon terraces and bunds help to hold the water in the paddy fields. Terracing and bunds are proven to be excellent measures of the SWC in the watershed. On the other hand, marginal farmers focus more on agronomic/biological measures as these conservation measures require less investment of capital and give higher returns in lesser time. Mechanical measures require higher construction and maintenance cost and during initial years productivity is low. Due to the poor economic conditions, marginal farmers are highly dependent on financial aid from government schemes to support the construction of mechanical measures. Marginal farmers are also more inclined and interested in growing cash crops as it requires less investment. Farmers are well aware of the value of crop rotation and shared that allocating the land for single crop per year is considered as an inefficient use of land. Similar results have been identified by various studies all over the globe (Metcalfe and Elkins, 1980; Unger, 1984; Francis and Clegg, 1990; Bullock, 1992; Reeves, 1994). The rotations of crop typically increase production compared to continuous cropping (Metcalfe and Elkins, 1980; Crookston et al., 1991; Lund et al., 1993). Mulching refers to the covering of surface soil by leaves, straw and grasses. The primary function of covering the ground is to protect soil from erosion and prevent the loss of soil nutrients through leaching and runoff (Reeves, 1994). Mulches help to minimise soil erosion, soil moisture evaporation and improve the fertility of the soil. With the use of rice straw mulching reduction in soil runoff up to $18 \%$ was reported in Kathmandu, Nepal (Atreya et al., 2008).
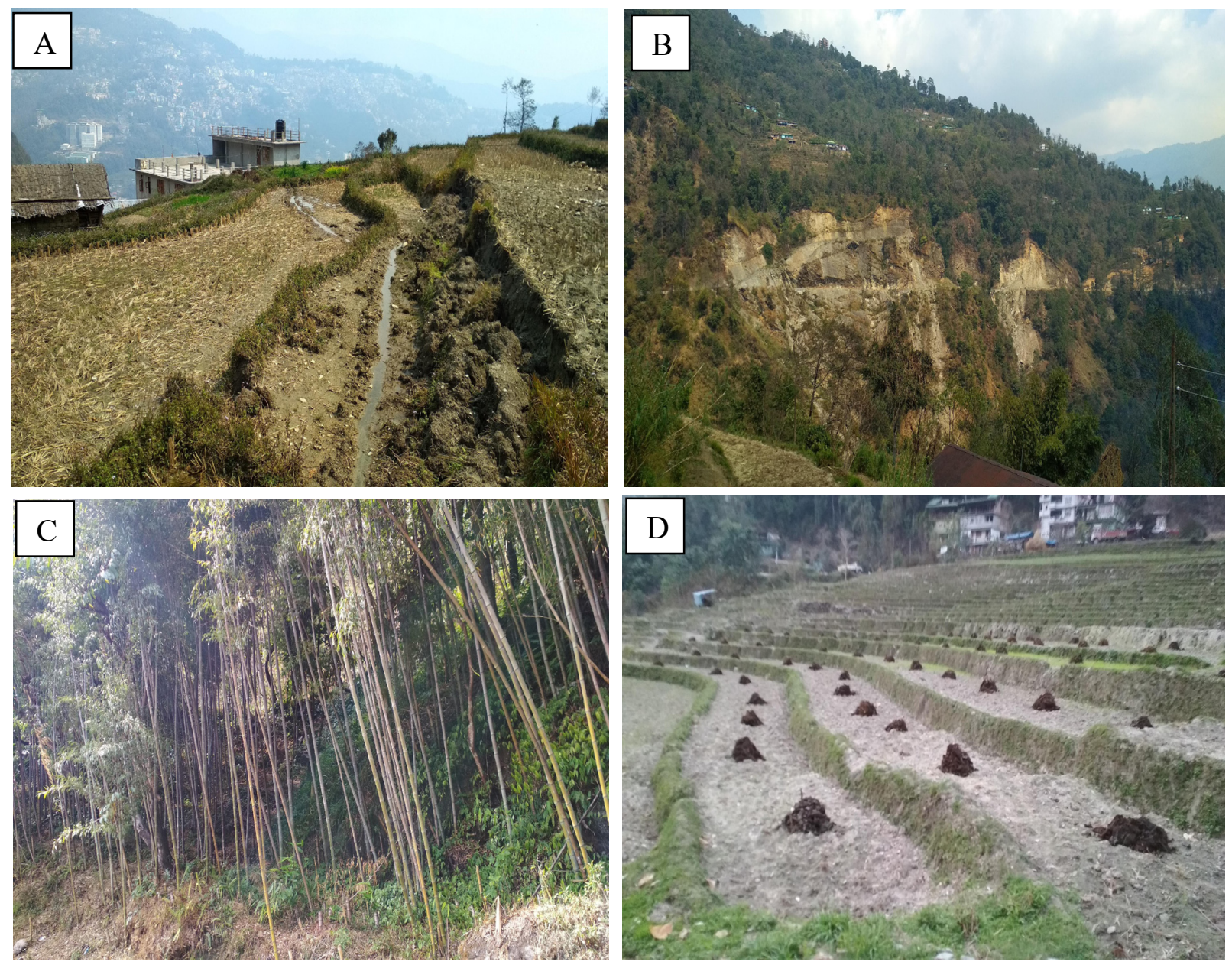

Fig4. Photograph showing (A) Terrace failure; (B) Landslides; (C) Bamboo trees plantation; (D) FYM

American Research Journal of Agriculture

Page 12 
The popularity of these agronomic measures depicts the role of these practices in the farming system of the watershed. The major reason behind the widely adopted practices is their higher yield capacity per unit area and diversification of crops. The increase in yield associated with crop rotation that is attributed to various factors such as erosion control, better weed management and increased soil nitrogen. When a legume is included in the crop rotation cycle, it results in increased soil organic matter content, improvement of physical soil conditions and reduction in losses from diseases and pests (Metcalfe and Elkins, 1980; Reeves, 1994). Agroforestry (52.3\%) and green manure (58\%) are also widely adopted measures to soil fertility and check soil erosion in the watershed. Various studies have reported the ecological and economic benefits of agroforestry practices (Sharma et al., 1997; Sharma et al., 2009; Mishra et al., 2013) in Sikkim Himalaya.

Alley cropping, fallowing and crop residue burning are among least practised SWC practices of the watershed. Due to marginal land holdings, poverty and increasing pressure on limited land for higher production. All the conservation methods are popular among all type of farmers. Agronomic measures of SWC in the watershed are a widely used technique as the majority of the farmers in the watershed are marginal, and pressure on land is very high to meet the demands of the growing population. Apart from the use of these measures in agricultural land, agronomic measures are also used to prevent gully erosion and slope failure. According to farmers planting bamboos trees along with the construction of stone walls to stabilise the land is the best way to tackle the problem. Bamboos species planted in gullies retain surface runoff and gaps between bamboo clumps are usually filled with stone walls. These gully control measures are constructed by $61 \%$ of the total respondents. Planting various fodder plants and trees such as Napier, Amlisho Nebharo, Badahar, Nimaro, Khanyu, Gagun, Mahula, Bakaino, Kabra, Khanium on sloppy lands stabilize and strengthen the slope by roots of the trees to prevent it from landslides and slope failure. However, for the long term soil water conservation, agronomic measures are required to be employed with mechanical measures to get better results.

\section{CONCLUSION}

Farmers are using traditional knowledge of SWC measures as an integral part of the farming system. Major indigenous SWC practices widely used by the farmers of the study are mechanical measures, agronomic/ biological measures and soil fertility measures to improve the effectiveness of the land management. For increasing production the majority of the farmers mostly integrate all the practices, but economic constraints restrict farmers to adopt all the SWC at a time. As agronomic measures are cost-effective and help in the conservation of soil and water resources in the agricultural fields, marginal farmers are highly dependent on these practices for diversifying their production system. Agronomic measures are used to increase productivity level with the help of a variety of crops, mixed cropping, crop rotation, by reducing soil erosion, improving soil health and livelihood. Soil and water resources present in the watershed are sufficient to sustain agriculture production system, but problems such as erosion of soil, small landholdings, inappropriate land management, diseases and pest in crops, overpressure on cultivated land have emerged as critical causes of land degradation and food insecurity in the watershed. Loss of traditional SWC measures is a threat to the valuable knowledge that has helped farmers of Sikkim to manage their agricultural lands for generations effectively. The traditional knowledge of SWC needs to be conserved and passed on to the coming generation for effective land management. Policies should focus on improvement and support of marginal farmers who are the real land managers of the study area. Participation of local representatives should also be considered while decision making and planning and preferences should be given to priority areas where the rate of land degradation is highest and agronomic SWC practices must be implemented to achieve sustainable farming.

\section{Acknowledgements}

The authors are thankful to the Indian Council of Social Science Research (ICSSR) New Delhi, India for financial support [F. No 02/298/2016/17/ICSSR/RP] to carry out the research. We also thank farmers of Sikkim Himalaya for participating in the research.

American Research Journal of Agriculture

Page 13 


\section{REFERENCES}

1. Ajibade, L.T. A. (2003). Methodology for the collection and evaluation of farmers" indigenous environmental knowledge in developing countries. INDILINGA: African J Indigen Knowl Syst 2, 99-113.

2. Atreya, K., Sharma, S., Bajracharya, R.M. and Rajbhandari, N.P. (2008). Developing a sustainable agro-system for central Nepal using reduced tillage and straw mulching. J. Environ. Manag. 88, 547-555.

3. Bullock, D. G. (1992). Crop rotation. Crit. Rev. Plant Sci. 11, 309.

4. Carson, B. (1985). Erosion and Sedimentation Processes in the Nepalese Himalya; ICIMOD Occasional Paper No. 1; ICIMOD: Kathmandu, Nepal.

5. Census of India (2011). Sikkim. 2011 Sikkim Census Report. http://censusindia.gov.in/2011census/ dchb/1100_PART_A_DCHB_SIKKIM.PDF (accessed on 19 $9^{\text {th }}$ March 2019).

6. Chalise, D., Kumar, L., Shriwastav, C.P. and Lamichhane, S. (2018). Spatial assessment of soil erosion in a hilly watershed of Western Nepal. Environ. Earth Sci., 77, 685.

7. Crookston, R.K., Kurle, J.E., Copeland, P.J. and Ford, J.H. (1991). Lueschen, W.E. Rotational cropping sequence affects yield of corn and soybean, Agron. J. 83, 108.

8. FAO. (1984) Guidelines: Land Evaluation for Rainfed Agriculture. FAO Soils Bulletin 52.

9. Francis, C. A. and Clegg, M. D., (1990). Crop rotations in sustainable production systems, in Sustainable Agricultural Systems, Edwards, C. A., Ed., Soil and Water Conservation Society, Ankeny, IA, 1990.

10. Garcia-Ruiz, J.M., Beguería, S., Lna-Renault, E. and Cerdà, A. (2017) Ongoing and emerging questions in water erosion studies. Land Degrad. Dev., 28, 5-21. https://doi.org/10.1002/ldr.2641.

11. Gardner, R. and Gerrard, A. (2003). Runoff and soil erosion on cultivated rainfed terraces in the Middle Hills of Nepal. Appl. Geogr. 23, 23-45.

12. Garrity, D. P., Stark, M., and Mercado, Jr. A. (2004). Natural Vegetative Strips: a bioengineering innovation to help transform smallholder conservation Science Publishers Inc. Enfield, USA. (pp. 263-270).

13. Gautam, D.R. (1993). Environmental Risk in Nepal: A General Assessment. Tribhuvan Univ. J. 16, 87-93.

14. Hawtin, G. C. And Mateo, N. (1990). Mountain agriculture and crop genetic resources, in Proceeding of International Workshop on Mountain Agriculture and Crop Genetic Resources, Riley K. W.; Mateo, N.; Hawtin, G. C.; Yadav R. Eds.; Kathmandu; New Delhi: Oxford and IBH Publishing Co. Pvt. Ltd, 14-23.

15. IIRR. (1996). Recording and Using Indigenous Knowledge: A manual. International Institute for Rural Reconstruction (IIRR), Silang, Cavite, Philippines.

16. Lalonde A. (1991). African Indigenous Knowledge and its Relevance to Environment and Development Activities. Environment and Development Consultant, R.R. 3, Wakefield, Quebec, Canada.

17. Lund, M.G., Carter, P.R. and Oplinger, E.S. (1993). Tillage and crop rotation affect corn, soybean, and winter wheat yields, J. Prod. Agric. 6, 207.

18. Maetens, W., Poesen, J. and Vanmaercke, M. (2012). How effective are soil conservation techniques in reducing plot runoff and soil loss in Europe and the Mediterranean? Earth-Sci. Rev. 115, 21-36. https://doi. org/10.1016/j.earscirev.2012.08.003

19. Manivannan, S., Kasthuri Thilagam, V. and Khola, O.P.S. (2017). Soil And Water Conservation In India: Strategies And Research Challenges, Journal Of Soil And Water Conservation. 16, 4, 312-319, Doi: 10.5958/2455-7145.2017.00046.7 
Agronomic Measures in Traditional Soil and Water Conservation Practices in the Sikkim Himalaya, India

20. Metcalfe, D.S. and Elkins, D.M. (1980). Rotations and cropping systems, in Crop Production Principles and Practices, 4th ed., Macmillan, New York, USA, chap. 14.

21. Mishra, P.K. (2017). Assessment of Run-off and Soil Loss under different Land-use Practices in a Himalayan Watershed, India. American Research Journal of Humanities and Social Sciences 3, 1-10.

22. Mishra, P.K. and Rai S.C. (2013). Use of indigenous soil and water conservation practices among farmers in Sikkim Himalaya. Indian J. Tradit. Know. 123 454-464.

23. Mishra, P.K. and Rai, S.C. (2014). A Cost-Benefit Analysis of Indigenous Soil and Water Conservation Measures in Sikkim Himalaya, India. Mt. Res. Dev. 34. 27-35. 10.1659/MRD-JOURNAL-D-12-00013.1.

24. Mishra, P.K., Rai A. and Rai S. C. (2019). Land use and land cover change detection using geospatial techniques in the Sikkim Himalaya, India, The Egyptian Journal of Remote Sensing and Space Sciences. https://doi. org/10.1016/j.ejrs.2019.02.001 [in press]

25. Morgan, R.P.C. (2005). Soil erosion and conservation. 3rd ed., Blackwell Science Limited, England. pp. 315 https://doi.org/10.1111/j.1365-2389.2005.0756f.x

26. Mountjoy, D.C. and Gliessman, S.R. (1988). Traditional management of a hillside agroecosystem in Tlaxcala, Mexico: an ecologically based maintenance system. Am. J. Altern. Agric. 3, 3-10. doi: 10.1017/ S0889189300002058

27. Mulat, Y. (2013). Indigenous knowledge practices in soil conservation at Konso People, South western Ethiopia. J Agric Environ Sci., 2, 1-10.

28. Rai, S.C. and Sharma, E. (1995). Land-use change and resource degradation in Sikkim Himalaya: A case study from the Mamlay watershed. In Sustainable Reconstruction of Highland and Headwater Regions. Singh, R.B.; Haigh, M.J. eds.; Oxford \& IBH Publishing Co. Pvt. Ltd., New Delhi. pp. 265-278.

29. Rai, S.C. and Sharma E. (1998). Comparative assessment of runoff characteristics under different land-use pattern within a Himalayan watershed. Hydrological Processes. 12 2235-2248.

30. Rai, S.C. and Sharma, E. (1998). Hydrology and nutrient flux in an agrarian watershed of the Sikkim Himalaya, J Soil Water Conserv, 53, 125-132.

31. Rai, S.C., Sharma, E and Sundriyal, R. C. (1994). Conservation in Sikkim Himalaya: traditional knowledge and land-use of the Mamlay watershed. Environ. Conserv. 21, 30-34, 56.

32. Reeves, D. W. (1994). Cover crops and rotations, in Crops Residue Management, Lewis Publishers, Boca Raton, FL, , 125.

33. Sanders, D. (2004). Soil Conservation, in Land Use ,Land Cover and Soil Sciences, [Ed. Willy H. Verheye], in Encyclopedia of Life Support Systems (EOLSS), Developed under the Auspices of the UNESCO, Eolss Publishers, Oxford, UK, [http://www.eolss.net]

34. Selby, M.J. (1993). Hillslope Materials and Processes. Oxford Univ Press, Oxford, England.

35. Sharma, E., Rai, S.C.and Sharma, R. (2001). Soil, water and nutrient conservation in mountain farming systems: Case study from the Sikkim Himalaya. Journal of Environmental Management, 6, 123-135.

36. Sharma, G., Sharma, R., and Sharma, E. (2009). Traditional knowledge systems in large cardamom farming: biophysical and management diversity in the Indian mountainous regions. Indian Journal of Traditional Knowledge 8 (1): 17-22.

37. Sharma, R., Sharma, E., and Purohit, A. N. (1997). Cardamom, mandarin and nitrogen-fixing trees in 
Agronomic Measures in Traditional Soil and Water Conservation Practices in the Sikkim Himalaya, India

agroforestry systems in India's Himalayan region. II. Soil nutrient dynamics. Agroforestry Systems 35: 235253.

38. Subba, J.R. (2009). Indigenous knowledge on bio-resources management for livelihood of the people of Sikkim Indian J. Tradit. Know. 8 (1) 56-64

39. Tidemann, E. M. (1996). Watershed Management. Guidelines for Indian Conditions. Omega Scientific Publishers. New Delhi.

40. Triplett, G. B. (1986). Crop management practices for surface-tillage systems, in No-Tillage and surface tillage Agriculture. The Tillage Revolution, Sprague, M. A.; Triplett, G. B. Eds.; John Wiley \& Sons, New York, 149.

41. Uddin, K., Murthy, M., Wahid, S.M. and Matin, M.A. (2016). Estimation of soil erosion dynamics in the Koshi basin using GIS and remote sensing to assess priority areas for conservation. PLoS ONE , 11, e0150494.

42. UNCCD (United Nations Convention to Combat Desertification). A carrying pillar in the global combat against land degradation and food insecurity. Background Paper for the San Rossore Meeting 'Climate Change: A New Global Vision', Pisa, Italy, 15-16 July 2004. UNCCD Secretariat.

43. Unger, P. W. (1984). Tillage Systems for Soil and Water Conservation, Food and Agriculture Organization of the United Nations, Rome, World Health Organization, Geneva, FAO Soils Bull. 54.

Citation: Prabuddh Kumar Mishra, Aman Rai, Suresh Chand Rai. "Agronomic Measures in Traditional Soil and Water Conservation Practices in the Sikkim Himalaya, India". American Research Journal of Agriculture, vol 5, по. 1, 2019, pp. 1-16.

Copyright (c) 2019 Prabuddh Kumar Mishra, Aman Rai, Suresh Chand Rai. This is an open access article distributed under the Creative Commons Attribution License, which permits unrestricted use, distribution, and reproduction in any medium, provided the original work is properly cited. 